\title{
The Estonian Mycological Collections of Heinrich August Dietrich (1820-1897)
}

\author{
Kadri Pärtel \\ Institute of Ecology and Earth Sciences \\ University of Tartu \\ Ravila 14A \\ Tartu 50411, Estonia \\ Mycological Collections \\ Institute of Agriculture and Environmental Sciences \\ Estonian University of Life Sciences \\ Kreutzwaldi 5 \\ Tartu 51006, Estonia \\ Email: kadri.partel@ut.ee
}

\section{Ave Suija}

Institute of Ecology and Earth Sciences

University of Tartu

Lai 40

Tartu 51005, Estonia

Natural History Museum and Botanical Garden

University of Tartu

Vanemuise 46

Tartu 51014, Estonia

Email: ave.suija@ut.ee

\section{Iryna Yatsiuk}

Institute of Ecology and Earth Sciences

University of Tartu

Ravila 14A

Tartu 50411, Estonia

Email: iryna.yatsiuk@ut.ee

\begin{abstract}
Heinrich August Dietrich was a gardener with a deep interest in mycology. He published a two-volume monograph dealing with over 1,000

$1 \quad$ This work was supported by the Estonian Research Council grant no. PRG1170 and by Estonian Ministry of Education and Research, from the scientific collection infrastructure program.
\end{abstract}


fungal and fungal-like taxa, the first cryptogamic research of this kind for the Baltic region. Between 1852 and 1857, H. A. Dietrich issued nine volumes of exciccatae named Centuria Plantarum Florae Balticae cryptogamarum. The preserved eight Centuriae and additional collections from Estonia (then the Imperial Russian Baltic province, Estonian Governorate) are revised and their current status in collections is presented. As a result, a new myxomycete species for Estonia, Physarum gyrosum, and the once doubtfully-reported species, Arcyria oerstedii, are recorded, and the earliest vouchers of some endangered ascomycetes, such as Poronia punctata and Sabuloglossum arenarium, are identified in his material. The most remarkable findings among lichenized fungi are Alectoria sarmentosa, Dibaeis baeomyces, Flavoparmelia caperata, Lasallia pustulata, Nephroma laevigatum, Peltigera venosa and Ramalina calicaris, as well as the oldest Estonian specimen of Lobaria pulmonaria.

Keywords: endangered species, Estonian Naturalists Society, historical voucher specimens, lichenized fungi, myxomycetes, taxon occurences

Der Wunsch nützlich zu sein, hat mir die Annehmlichkeiten, die mir im Beobachten und Sammeln dieser unendlich reichen Gestaltenwelt in Wald und Feld und Garten entgegentraten, doppelt erhöht und versüßt; möchte ich nicht zu fern von meinem Ziele geblieben sein.

(Dietrich, 1856, p. 261)

\section{Introduction}

The diverse fungal kingdom has been of scientific interest in the Baltic region since the days of Carl von Linné, when current Estonia, Latvia and the northern part of Lithuania belonged to the Russian Empire as Baltic provinces (in German Russische Ostseeprovinzen). The oldest written evidence about fungi was published by J. B. Fischer (listed 24 taxa; Fischer in Hupel, 1777; Fischer, 1791), a student of Linné for a short period, and about lichenized fungi by J. G. Zigra (8 taxa; Zigra, 1799), a pharmacist in Valga (Valka). Although Grindel (1803; 59 taxa) and Friebe (1805; 31 taxa) later included (macro)fungi in their floras, the number 
of regionally known fungi did not change significantly for about 50 years. The taxonomic names in these historical sources are often difficult to interpret due to the brevity of descriptions and lack of voucher specimens. Fischer, Grindel and Friebe were all connected with the city of Riga, the capital of the Livonian Governorate (in German Livland, nowadays the southern part of Estonia and northern Latvia), and, in writing their books, they clearly did not travel to the Estonian Governorate (Est(h)land, nowadays only the northern part of Estonia). Therefore, their fungal records are restricted to Livonia, an administrative unit that disapperead ca 100 years ago. These books represent the oldest mycological sources for current Latvia (Vimba, 2009).

In 1856, Heinrich August Dietrich (1820-1897) published the next generation book, Blicke in die Cryptogamenwelt der Ostseeprovinzen. This publication and its second volume three years later (Dietrich, 1856; 1859) represented major progress in terms of numbers of species. He mentioned 1,092 species from 173 genera and introduced several taxonomic novelties. In addition to boletes, agarics and some polypores, previously cited by Fischer, Grindel and Friebe, Dietrich's book also dealt with microfungi, especially plant parasites, and lichens, as well as fungal-like life forms such as myxomycetes and oomycetes. Most important from a scientific perspective are Dietrich's exciccatae that are referred to in Cryptogamenwelt, which are available for further investigations and include voucher specimens from Estonia from the middle of the 19th century.

This paper is dedicated to Heinrich August Dietrich, whose 200th birth anniversary was celebrated in 2020. Dietrich was a distinguished garden specialist and a father of Estonian mycology, even though his life history is anything but well known. This anniversary provided a good reason to take his heritage from "dusty shelves", to revise these oldest, forgotten collections of Estonian fungi and fungal-like organisms, and introduce them to the wider mycological community. Discomycetes, in particular Helotiales, lichenized fungi and myxomycetes were the special focus because these groups had not been treated by researchers working with these collections previously. 


\section{Methods}

Specimens were examined under the stereomicroscope. When necessary, microsctructures were studied using razor-blade-cut sections mounted in tap water, in 3-10\% potassium hydroxide $(\mathrm{KOH} ; \mathrm{K})$ and Melzer's solution under the light microscope. Myxomycetes microstructures were mounted in lactophenol cotton blue (LCB) or tap water. Spot tests using paraphenylenediamine ethanol solution (Pd), commercial bleach ACE containing sodium hypochlorite (C), or $\mathrm{K}$ were used for detecting the presence of some lichen substances.

The nomenclature of fungi follows Index Fungorum (n.d.) and that of Myxomycetes Nomen Eumycetozoa (Lado, 2005-2021). The material is kept in the fungal collection of the Estonian University of Life Sciences (scientific collection acronym TAAM) in Tartu and in the Estonian Museum of Natural History (TAM) in Tallinn.

Locality data were determined using the Estonian-German list of place names (Kongo, 2016), the Place Names Database (KNAB, n.d.) and the database Estonian Manors (n.d.). To ensure the concordance of toponyms, historical names used by Baltic Germans are given in brackets following the official Estonian name when first mentioned; for example Haimre (Heimar).

\section{The life of H. A. Dietrich}

Heinrich August Dietrich was born on 4 November 1820, in Zwenkau, Kingdom of Saxony (now Germany, ca $15 \mathrm{~km}$ south from Leipzig) as the son of a lawyer Wilhelm August Dietrich (EAA, 1699-1939). His forename has been written as August Heinrich or Heinrich August or Adam August Heinrich, or August, in different documents (Parmasto, 2009). Here we use the version of his name suggested in the list of Fungal Authors (Index Fungorum, n.d.). It is known that he lost his parents early in life (Sander, 2019), but there is no documented evidence about his education. Perhaps it is not a coincidence that young Dietrich became a gardener as was his uncle. He emigrated as a trained specialist (Kunstgärtner) to the Western part of the Estonian province of the Russian Empire. Dietrich was employed there by von Uexküll in the Haimre manor (Heimar in Wiek, the last word referring to the historical Lääne County) near Märjamaa, now Rapla County. 
It is difficult to determine the exact year when Dietrich arrived in Estonia but, according to the Oleviste church register (TLA, 1834-1905), in October 1849, he married Eleonore Mathilde Elisabeth Neudorf (1827-1906), who was born in Tallinn (Reval). Most probably, Dietrich had already been living there for some years by that time. This assumption is consistent with the data of the oldest Dietrich's collection, compiled ca 1845-1850 in the vicinity of Haimre (Lepik, 1940).

Dietrich worked until approximately 1857 as the Inspector of Gardeners and Learned Gardener in Haimre manor (Garteninspector and Privatgarteninspector, see Anonymous, 1855-1856a; 1855-1856b). When the Estonian Naturalists Society (Die Dorpater Naturforscher-Gesellschaft) was established in 1853, Dietrich was active as a corresponding member from 10 October 1853. From December 1856 he became a corresponding member of Riga Naturalists Society (EAA, 1863-1864; Anonymous, 1855-1856b).

It appears that from 1857, the permanent residence of Dietrich's family was Tallinn; at least their fourth child was baptized there in June 1857 (TLA, 18571885), whereas older siblings (he had one son and five daughters) were registered in Läänemaa (EAA, 1699-1939; Sander, 2019). Probably two years later, his main activity turned to garden business. Dietrich owned a tree nursery and a Market Garden in Tallinn (Domvorstadt 175, now Kevade Street 5/7) (EAA, 1879). He collected plants and compiled the herbarium Flora Revalensis 1862 (Sander, 2019) and published a list of Estonian woody plants (Dietrich, H. A., 1865).

He was one of the founders of the local Gardening Society (Ehstländischer Gartenbauverein $z u$ Reval) and, from 1862, served as a secretary of this organisation. Dietrich was also active in gardening exhibitions, and popularized new suitable, edible or decorative plants and vegetables, as well as new gardening methods (Dietrich, 1854; 1864; Dietrich, A., 1865; Kask, 1960; Sander, 2019).

Dietrich died on 21 December 1897 in Tallinn, as a citizen of Saxony but wellknown in Tallinn. According to his obituary, he was a man full of humor and wittiness, and a vigorious and warm person (Revalsche Zeitung, 1897). 


\section{Mycological activity of H. A. Dietrich Publications}

In addition to his everyday work in horticulture, the 1850 s and the beginning of the next decade were very fruitful in Dietrich's life as a mycologist. He compiled nine volumes of exciccatae, Centuria Plantarum Florae Balticae cryptogamarumthe earliest in the Baltic region, and, on the basis of these collections, issued the monograph Blicke in die Cryptogamenwelt der Ostseeprovinzen (Dietrich, 1856; 1859) (Fig. 1). He wrote a poetical paper about birch-associated organisms, mostly addressing fungi on leaves and wood, myxomycetes, lichens and mosses, as a consistent unit in nature (Dietrich, 1860). As a taxonomist, he tried to form his own concept about the systematics and classification of fungi, lichens and algae, which he called "niedere Pflanze" (Dietrich, 1861). Unfortunately, after 1861, he never returned to his initial mycological interests.

In 1857, he spent half a year in St. Petersburg, studying mycological literature and working at the herbarium of the Russian Academy of Sciences. Here he had an opportunity to examine some private collections as well as to discuss ongoing research with the Academician Dr. Franz J. Ruprecht (1814-1870) and the mycologist Ilya G. Borszschow (Borshchov, 1833-1870), both of whom Dietrich later acknowledged for their help during this period (Dietrich, 1859, p. 488). He issued the last series of his exciccatae, Centuria $I X$, in 1857, and, on 12 November that same year, he was awarded the Silver medal of the Kaiserliche freie ökonomische Gesellschaft zu S. Peterburg for his cryptogamic collections (EAA, 1863-1864). His scientific achievements were acknowledged in 1863, when he was awarded the title of Honorary Citizen (persöhnliche Ehrenbürger) by the

Arch. S. 400 .

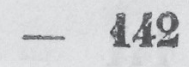

47. Agaricus muscarius L. Rabenh. 4050. Weinm. 5. Grindel 329. Fiścher 741. Friebe 341. (lett. Muschmirres, ehstn. Kerbse-sened, russ. Myxоморz).

Nicht häufig in Ehstland, in gemischten Wäldern, vom Sommer bis zum Herbst.

Figure 1. A fragment of page 400 in Blicke in die Cryptogamenwelt der Ostseeprovinzen I (Dietrich, 1856). 
Kadri Pärtel

Ave Suija

Iryna Yatsiuk

Russian Tsar (EAA, 1863-1864) (see Dietrich's signature in the arhive folder of documents connected with this event in Fig. 2).

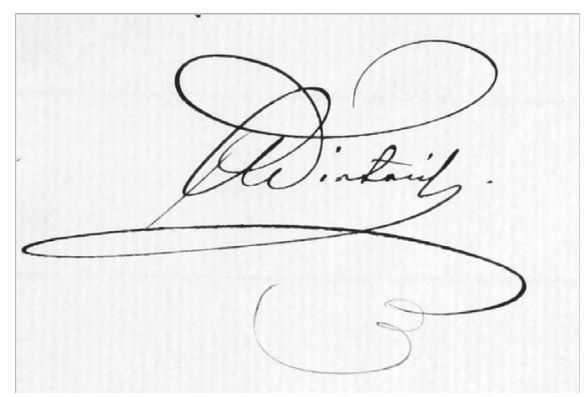

Figure 2. The signature of Heinrich August Dietrich in Estonian National Archives EAA.29.3.5543.11 (EAA, 1863-1864).

Dietrich referred to three books as the sources for his research (Weinmann, 1836; Fries 1816-1836; Rabenhorst, 1844-1848). Each taxon given in the Centuria is referenced by the page number in these publications. He actively collaborated with several well-known naturalists of that time. He acknowledged Carl August Heugel (1802-1876) in Riga for descriptions of Baltic lichens (Dietrich, 1859, p. 489). Several taxa in Dietrich's fungal collection originate from the plant exciccatae of Alexander von Bunge (1803-1890), a medical doctor, botanist and plant systematist (Dietrich, 1856, pp. 279, 288, 310). In addition, Dietrich has notes for some species such as Häufger in Dorpat's Umgebung with Hofr. Girgensohn as the collector (Dietrich, 1856, pp. 406, 407, 411, 413; 1859, p. 521), referring to Gustav Carl Girgensohn (1786-1872), an amateur bryologist and high school teacher from Tartu whose mycological collections were revised recently (Pärtel et al., 2021).

\section{Study area}

Dietrich made his fieldtrips mainly in the historical Wiek County in Märjamaa (Merjama) parish. The manors in Märjamaa parish are the most frequent localities mentioned in his Cryptogamenwelt I (Dietrich, 1856) and in specimen labels in Centuriae I-VIII. Besides the home manor Haimre, he mentions Kasti (Casty), Kunsu (Kunzekülla), Märjamaa, Naistevalla (Naistewalle), Orgita (Rosenthal), Sulu (Sullo), Sôtke (Söttküll), Tolli (Parjenthal), Valgu (Walk). Localities in neighbour parishes were Jädivere (Jeddefer), Kloostri (Löwenberg), Lihula (Leal), Matsalu (Matzal), Oidrema (Oidenorm), Puhtu (Pucht), Vana- 
Vigala (Altfickel), Velise (Felks) and Virtsu (Werder); all these localities are up to $80 \mathrm{~km}$ from Haimre. In the historical Harju County, Dietrich sometimes visited manors close to the northern coast: Keila-Joa (Fall), Viimsi (Wiems) and Vääna (Fähna), as well as the surroundings of Tallinn and Kadriorg (Katharinenthal). Pärnu (Pernau) and Kóima in Mihkli parish in the historical Pärnu County (Kreis Pernau) were both cited once.

Only the last Centuria $I X$ was collected during a summer vacation in Tallinn and its specimens are referred to in Cryptogamenwelt II (Dietrich, 1859). Localities in this work are Tallinn (bei Reval, Glintregion Reval), Kadriorg and Pirita (Brigitten um Reval), as well as Haimre (16 times), Kasti, Lihula, Valgu and Velise, known already from the Cryptogamenwelt I. One species was observed in St. Petersburg in the summer of 1857 (Dietrich, 1859, p. 518).

\section{Habitats and substrates of studied cryptogams}

The Cryptogamenwelt (Dietrich, 1856; 1859) and collection labels indicate that Dietrich made his observations in fields, pastures and forests, heaths and bogs, as well as in the surroundings of manor gardens and parks. He wrote about some fungal species, "alljährlich im Heimar'schen Garten", demonstrating that he made continuous observations year by year. According to the substrate data of more than 800 preserved specimens collected by him, about half of the specimens (425) were growing on leaves of various, mainly native plants, nine were listed on seeds, and eight on inflorescences. In manor flowerbeds and from the caldarium (greenhouse), he collected fungi on cultivated exotic plants (e.g., Antirrhinum, Camellia, Crinum, Cytisus, Nerium and Schizanthus). During 1920-1940, Karl Eichwald (1899-1976), who worked for the herbarium of the University of Tartu, reexamined these host plants and, except for some taxa, was able to confirm most of Dietrich's identifications.

Dietrich studied fungi on vegetables, such as pumpkin peels, carrots, beans and potatoes, as well as those on cucumbers, peas and watermelons. About 150 preserved specimens were collected from trees or rotting wood, either in the forest and the orchard (apple, plum, cherry, pear trees) or in the park (including on introduced trees like Juglans regia, Pinus austriaca and Philadelphus coronaries). Some of the hosts/substrates were quite rare, such as dead butterflies or window glass, feathers or horns. On six times Dietrich collected fungi growing on basidiomata of agarics. Remarkably, he also noticed parasitic fungi on lichen thalli, Illosporium coccineum Fr., "aufeinem verwittertem Flechtenlager" (Dietrich, 1856, p. 328). 
Kadri Pärtel

Ave Suija

Iryna Yatsiuk

\section{Taxonomical novelties described by H. A. Dietrich}

Dietrich described a total of 62 new species (Aecidium 8 species, Asteroma 1, Cenangium 1, Cronartium 4, Depazea 18, Peziza 1, Puccinia 4, Sistotrema 1, Sphaeria 6, Sphaerotheca 5, Stereum 2, Uredo 11) and one variety of Thelephora (Dietrich, 1856; 1859). Half of these taxa are registered in the international fungal database Index Fungorum (n. d.), but only a few of them are connected with the current name. The descriptions are short or lacking, and therefore many taxa have the status of nomina nuda, even though most taxa remain unrevised by experts. In addition to new species, Dietrich is the author of 75 new forms (Parmasto, 2009).

\section{Collections of H. A. Dietrich}

\section{The first unpreserved collections}

1) Dietrich's oldest specimens were kept before the Second World War in the Phytopathological Institute of the University of Tartu, but these specimens have been lost. For the only evidence of this collection, dating from 1845-1850 and named Cryptogamarum in Estonia sponte nascentium, Centuriae I et II exciccatae, auct. Dietrich. Heimar bei Reval 1851, we can be grateful to Professor Elmar Leppik $^{2}$ (Lepik, 1940). According to this reference, this was the Dietrich's test or pilot collection before the Centuria series was issued. Based on handwritten lists of specimens, the collection included 133 specimens of fungi, 34 specimens of lichenized fungi, and an additional 32 other cryptogams: Algae, Musci, Hepaticae and Filicoideae.

2) A second lost collection was issued in 1854 and named 30 species Cryptogamen (meist Pilze) für Herrn candidat Schmidt gefälligst abzugeben. A. Dietrich. From Leppik (Lepik, 1939), it can be deduced that this collection comprised 100 specimens of mostly rust fungi, together with other parasitic fungi, found in the surroundings of Haimre in 1848-1851. Leppik (Lepik, 1939) compiled a complete list and revision of this collection of which the present status in unknown.

Elmar Lepik (born 1898 in Jógevamaa, Estonia; died 1978 in Beltsville, USA) changed his name to Elmar Emil Leppik in 1950 in the USA (Kalling, 2013). 


\section{Preserved collections}

Before the 1940s, the Dietrich's mycological heritage, of which the most important part is the series of exciccatae, Centuria Plantarum Florae Balticae cryptogamarum, was in the possession of the Phytopathological Experiment Station of the University of Tartu, Estonian Naturalists Society and the University of Tartu Botanical Gardens (Lepik, 1928; Kongo, 2003, p. 53). After the Second World War, all exciccatae in Tartu were gathered together and are now managed by the Estonian University of Life Sciences.

The collections owned historically by the Baltic-German society $E(h)$ stländische Literärische Gesellschaft in the Provincial Museum are now kept in the Estonian Museum of Natural History in Tallinn. Those Centuriae that Dietrich sent to Riga (Anonymous, 1855-1856a) appear to be lost according to correspondence with Latvian museums. Dietrich's specimens that were historically owned by Die Kaiserliche Freie Ökonomische Gesellschaft zu Sankt Petersburg are now kept in the fungarium of the Komarov Botanical Institute of the Russian Academy of Sciences (LE) in St. Petersburg. These specimens have not been revised in the present study.

Five Centuriae are bound as books (see Table 1), with hard covers and a printed front page. Centuriae V and VII fungi are mounted on thin paper sheets and accompanied by a handwritten catalogue booklet. Centuria IX is organised as a folder.

Table 1. The current status of Centuria Plantarum Florae Balticae cryptogamarum.

TAAM: mycological collection of Estonian University of Life Sciences, TAM: the Estonian Museum of Natural History

\begin{tabular}{|l|l|l|l|}
\hline $\begin{array}{l}\text { Year of } \\
\text { issue }\end{array}$ & $\begin{array}{l}\text { Volume } \\
\text { number }\end{array}$ & Repository and number of copies & Forming \\
\hline 1852 & I & TAAM (3), TAM (1) & bound \\
\hline 1853 & II & TAAM (3) & bound \\
\hline $185 ?$ & III & Unpreserved & - \\
\hline 1854 & IV & TAAM (3), TAM (1) & bound \\
\hline 1854 & V & TAM (1) & folder \\
\hline 1855 & VI & TAAM (3) & bound \\
\hline 1856 & VII & TAM (1) & folder \\
\hline 1856 & VIII & TAAM (3) & bound \\
\hline 1857 & IX & TAAM (1) & folder \\
\hline
\end{tabular}




\section{Critical observations of the Centuriae specimens}

The rust fungi from Dietrich's exciccatae have been revised by different authors (Bucholtz, 1905; Arefyew, 1916; Lepik, 1928; 1931; 1938; 1939). Leppik also revised the smut fungi and powdery mildews (Lepik, 1943), but not other ascomycetes or agarics and polypores. The scant handwritten identifications and comments on sheets indicate that the material of some ascomycetes was checked by Ain Raitviir (1938-2006) and those of lichenized fungi by Professor Hans Trass (1928-2017).

For this overview, we examined all available herbarium material of lichenized fungi and myxomycetes, as well as discomycetes with preserved apothecia. With a few exceptions, the date and locality data are not indicated on labels, but the habitat (in hortis, in sylvis nostris, etc.) and the substrate (in Latin) are quite detailed, as is the frequency (rarissime, haudlminus frequens, non copiose, hinc. inde., perrara, ubique, per regionem) and phenology (primovere, aestate, autumno, hieme). We provide this information as it was originally written on the labels with original chapter titles (Fungi versus Lichenes). In some cases, locality data are given in Cryptogamenwelt (Dietrich, 1856; 1859) and therefore we can directly link the reference to the specimen. In many cases, the specimens are quite wellpreserved, and we were able to confirm or reidentify the specimen. We present here an annotated list where new identifications are written in bold.

\section{Centuria I}

Leppik listed 103 specimens instead of Dietrich's original 100 because, based on his expertise, three pages included two taxa. Taxonomical annotations of all specimens (one example in Fig. 3) are made by Leppik (Lepik, 1928) and were added by him as printed labels to two volumes. This Centuria included mostly plant parasites, with 55 specimens belonging to Pucciniales and 23 to Erysiphaceae.

\section{Centuria II}

This Centuria contains a total of 106 specimens (four Centuria pages have 2, one has 3 substrate plant species, which increased the original specimen number), including one myxomycete specimen. Leppik has revised 47 specimens of Pucciniales (Lepik, 1938), 2 of Ustilaginales and 8 of Erysiphaceae (Lepik, 1943). 


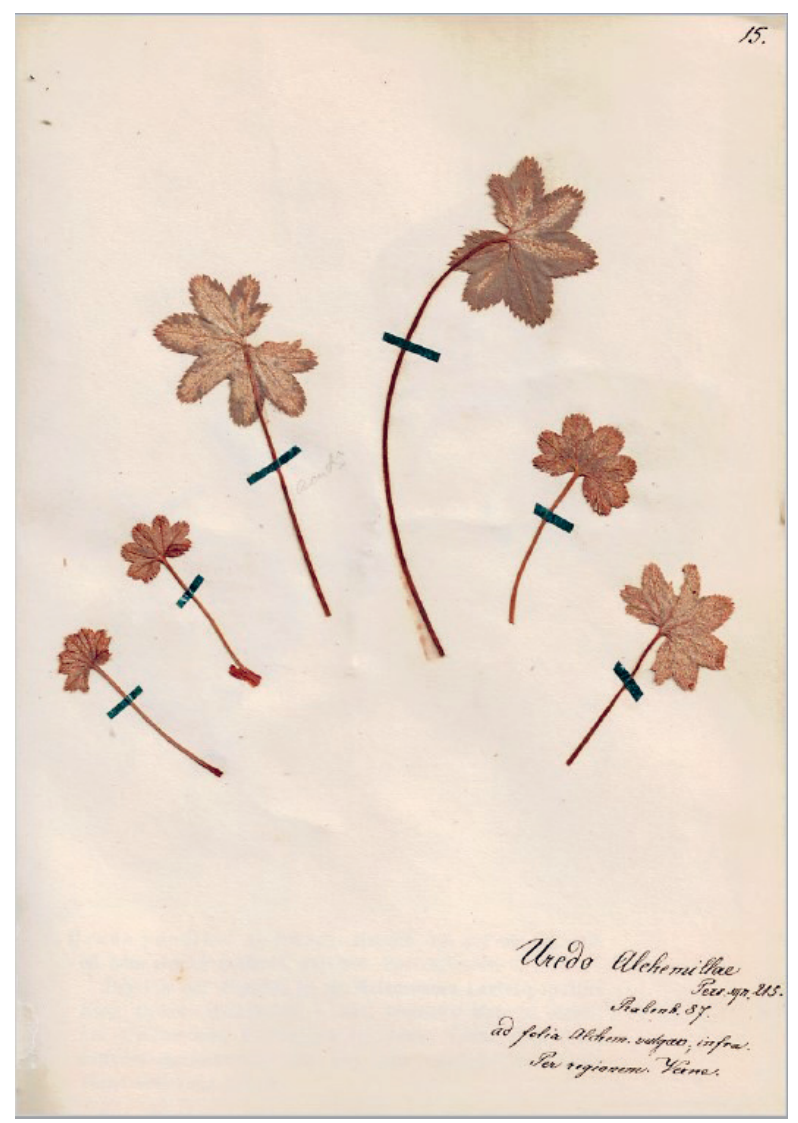

Figure 3. Example of a rust fungus in Dietrich's Centuria I 15: leaves of Alchemilla sp. infected with Uredo alchemillae (current name Trachyspora alchemillae (Pers.) Fuckel).

80. Stemonitis fusca Fr. St. fasciculata Pers. Ad putrid. truncos corticesque. Autumno per regionem. Stemonitis axifera (Bull.) T. Macbr. Det. I. Yatsiuk.

86. Cenangium Aucupariae Fr. ad sicc. ramos Sorbi Aucupar. Autumno-verne, per regionem. cf. Tympanis alnea (Pers.) Fr. Det. K. Pärtel. Primary spores globose aseptate.

87. Godronia ribis (Fr.) Seaver (as Cenangium ribis Fr.) ad annosos ramos Ribis rubri etc, per annum. Conf. K. Pärtel.

88. Peziza nivea Fr. ad putr. truncos et ramos, etiam ad sicc. ramos Syringae vulg. in hortis. Autumno-verne, rarius. Lachnum sp., det. K. Pärtel. Asci destroyed, but hairs are entirely warted typical to Lachnum, aseptate spores are 5-7 × 1.6-2 $\mu \mathrm{m}$. 
89. Peziza calycina Fr. ad sicc. ramos Pini sylv. et Abietis, autumno-verne. Per regionem. Current name is Lachnellula subtilissima (Cooke) Dennis. Rev. K. Pärtel. Many fruitbodies have only stipe base on bark, remained apothecia are juvenile, it is possible to confirm that it is Lachnellula sp.

90. Merismodes anomala (Pers.) Singer (as Peziza anomala Pers.) ad sicc. decidit. ramos per anum. Satis rare! Per regionem. Conf. K. Pärtel. Typical hairs. This taxon belongs now to Agaricales, Basidiomycota.

91. Brunnipila clandestinum (Bull.) Baral (as Peziza clandestina Fr.) ad ramos decidit. Ruborum etc. Autumno-verne. Ubique copiose. Conf. K. Pärtel.

92. Peziza setosa Nees. ad putr. truncos ramosque inter muscos etc. Aestateautumno, nusquam copiose. Per regionem. Current name is Scutellinia setosa (Nees) Kuntze, but for species-level confirmation material too scanty, Scutellinia sp., rev. K. Pärtel.

93. Helvella atra. In silvis humidis, inter muscos etc, autumn. Rarius! Esthonia. cf. Helvella atra J. König., conf. K. Pärtel. Ascospores 1-guttulate, 11-13.5 × $16.8-18 \mu \mathrm{m}$.

\section{Unpreserved Centuria III}

The material of this volume was already in bad condition in the 1930s (Lepik, 1938). The fungi were kept within loose paper envelopes in a wooden box, and were decayed and damaged by insects. The documentation of this material was insufficient as the list of contents and year of issue are lacking. Two species of rust are reported in this Centuria: Cronartium ribicola A. Dietr. and Aecidium cornumpiceae Rees (Lepik, 1938, p. 9). Based on Dietrich's monograph (Dietrich, 1856), Centuria III included polypores and other macrofungi; for example, Serpula lacrymans (Wulfen) J. Schröt. no. 74, from a house in Märjamaa (Dietrich, 1856, p. 384). Seven specimens of this Centuria have small duplicates in Dietrich's Fasciculi (see below).

\section{Centuria IV}

This Centuria contains 107 specimens in total (5 pages have more than one substrate plant), including one myxomycete and 20 lichenized fungi. Elmar Leppik revised in this volume 27 specimens of Pucciniales, four of Ustilaginales (Lepik, 1939), and 14 powdery mildews (Erysiphaceae) (Lepik, 1943). 
Fungi 1-80

65. Physarum sinuosum Weinm. Ph. bivalve Pers. In foliis et ramiis humi jacentibus provenit, ad muscos et ligna decorticata. Aestate per regionem. Physarum bivalve Pers. Conf. I. Yatsiuk. In the specimen are stems of three different plants, one a fern stem.

73. Peziza sulpurea Pers. Ad caules plantar. major (Arctior) Aestate, haud frequens. Trichopeziza mollissima Fuckel, det. A. Raitviir 1964.

\section{Lichenes 81-100}

81. Lecanora subfusca Ach. Ad cortices divers. arborum. Lecanora allophana (Ach.) Nyl. Det. I. Jüriado.

82. Lasallia pustulata (L.) Mérat (as Umbilicaria pustulata fr.) Ad saxa, praecipue in littoris regione. Conf. A. Suija. There is no locality data given on the sheet, but it is said in Cryptogamenwelt that this species is not rare on granite stones near coastal area, for example near Virtsu and Tallinn (Dietrich, 1856, p. 147).

83. Xanthoria parietina (L.) Th. Fr. (as Parmelia parietina). Ad cortices, sepes, saxaque. Ubique per orbem. Conf. A. Suija.

84. Melanohalea olivacea (L.) O. Blanco, A. Crespo, Divakar, Essl. D. Hawksw. \& Lumbsch (as Parmelia olivacea Ach.). Ad cortices divers. arborum. Ubique. Conf. A. Suija. The medulla reacts $\mathrm{Pd}+$ orange.

85. Parmelia saxatilis L. fr. Ad saxa, etiam ad arbores. Ubique. Xanthoparmelia somloensis (Gyeln.) Hale. Det. A. Suija.

86. Lobaria pulmonaria (L.) Hoffm. Ad div. arbores in sylvis. Satis frequens. Conf. A. Suija.

87. Sticta amplissima Scopol. Ad vetustos truncos, rarissime! Estoniae Longitudine and latitudine insigne excellit. Cyphellae saepius desunt ab mihi nondern observatae. Lobaria pulmonaria (L.) Hoffm. Det. A. Suija. Typical Ricasolia amplissima (Scop.) De Not. should have smooth thallus surface while in this specimen, ridges and depressions are typical to L. pulmonaria (Fig. 4). This is the only lichen specimen the existence of which in Estonia is indicated on the label. The "precise" locality, a forest near Valgu (Wäldern bei Walk in Ehstland) is given in the book (Dietrich, 1856, p. 148).

88. Lecidella elaeochroma (Ach.) M. Choisy (as Lecidea parasema Ach.) Ad cortices per regionem. Conf. A. Suija. 
Kadri Pärtel

Ave Suija

Iryna Yatsiuk

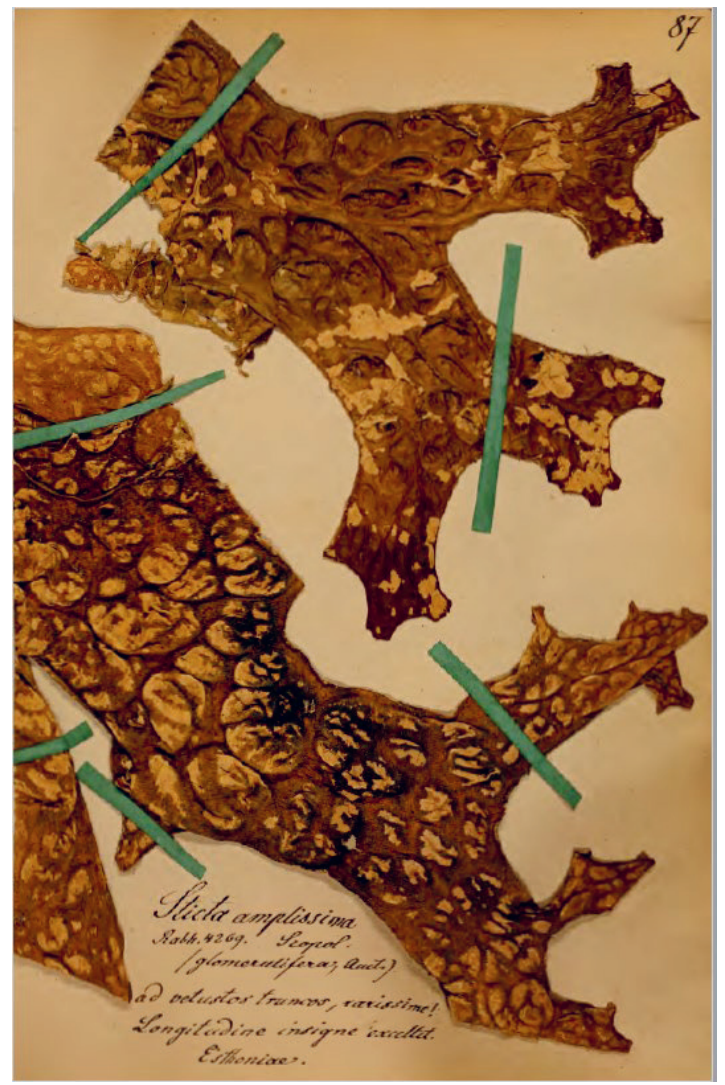

Figure 4. Example of a lichenized fungus in Dietrich's Centuria IV 87: thallus of Lobaria pulmonaria.

89. Cladonia rangiferina (L.) F. H. Wigg. Ad terram nudam in pinetis, et inter muscos, ubique. Conf. A. Suija.

90. Stereocaulon paschale L. In pinetis et ad terram, saxa, et ad vetust. truncos. Per regionem. Stereocaulon tomentosum Fr. Det. A. Suija. The thallus reacts Pd + orange.

91. Cetraria islandica (L.) Ach. In pinetis inter muscos, satis frequens. Conf. A. Suija.

92. Cetraria islandica (L.) Ach. Cum antecedent. Conf. A. Suija. Thallus reacts $\mathrm{Pd}+$ orange.

93. Vulpicida juniperinus (L.) J.-E. Mattsson \& M. J. Lai (as Cetraria juniperina). In pinetis ad terram, ad truncos Juniperi. Ubique. Conf. A. Suija. 
94. Anaptychia ciliaris subsp. ciliaris (L.) Körb. ex A. Massal. (as Hagenia ciliaris Fr.). Ad truncos Tiliarum, Salicum, etc. Ubique. Conf. A. Suija.

95. Evernia prunastri (L.) Ach. Ad truncos, ramos sepesque. Ubique. Conf. A. Suija.

96. Pseudevernia furfuracea var. furfuracea (L.) W. Mann. (as Evernia furfuracea L. fr.) Ad truncus, ramosque Pinorum, etc. Ubique Conf. A. Suija.

97. Ramalina fraxinea (L.) Ach. (as Ramalina calicaris b., fraxinea L.) Ad truncus ramosque vetust. arborum. Per regionem. Conf. A. Suija.

98. Ramalina calicaris (L.) Röhl. (as Ramalina calicaris c., caniculata fr.) Haud frequens ad truncos vetust. etc. Per regionem. Conf. A. Suija.

99. Bryopogon jubatus L. Lk. Ad vetust. truncos etc, inter muscos ad saxa. Ubique. Alectoria sarmentosa (Ach.) Ach. Det. A. Suija.

100. Usnea barbata, a campestris, b. hirta L. /monstr. prolif. Ad vet. sepes, trabes et ad saxa etc. Ubique. Est! Among the different Usnea species mentioned on the label, only Usnea hirta (L.) F.H. Wigg. is represented in this material. Conf. A. Suija.

\section{Centuria V}

Specimens of this Centuria are stuck to 14 thin paper sheets with a handwritten title, A. H. Dietrich Plantarum fl. Balt. Cent V. These sheets, with 2-8 specimens stuck by paper strips, are numbered $1-17$, from which sheets 5,13 and 14 are missing. Each fungus has a reference number written together with a Latin name on fungal sheets. Eleven numbers are absent or contain only a substrate. The handwritten list in a separate booklet is titled as Centuria $V$ continens Fungos et Lichenes. Here Leppik refers to only one rust fungus (Lepik, 1939). Small ascomycetes are in bad condition; for example, three specimens of Peziza fructigena have only stipes. This Centuria contains 18 lichen specimens, most of them in good condition, although a few are attached to sheets upside down, making confirmation of determinations difficult. Four specimens are myxomycetes.

Fungi 1-80

5. Ceratiomyxa fruticulosa (Müll.) Mac. (as Ceratium hydnoides Alb. et Schw.) Ad truncus vetust. Salicum, Alnorum, Pinorum, Verne-autmono. Minus rare. Conf. I. Yatsiuk. 
Kadri Pärtel

Ave Suija

Iryna Yatsiuk

16. Poronia punctata (L.) Fr. In fimo vaccine et equorum. Minus rare, verneautumno. Conf. K. Pärtel (Fig. 5A). In Dietrich (1856, p. 327), close localities, Keila-Joa and Vääna are mentioned.

21. Reticularia splendens Morgan (as Reticularia umbrina Fr.) Ad truncus vetust. div. arborum, aestate-autumno. Ubique. Conf. I. Yatsiuk.

22. Arcyria incarnata Pers. Ad ligna putracent. e.g. Pinorum, minus rare. Verneautumno. Est! Conf. I. Yatsiuk.

23. Diderma crustaceum Peck (as Spumaria physarioides DC.).

Herbas, folia etc aestate latissime obducens. Satis rare. Det. I. Yatsiuk.

37. Encoelia furfuracea (Roth) P. Karst. (as Peziza furfuracea Alb. et Schw.) ad ramos Coryli avellanae. Esthoniae, minus rare. Conf. K. Pärtel.

39. Peziza leporina Batch. In pinetis inter muscos, aestate-autumno, per regionem. Belongs to Otidea, but ascospores collapsed. Rev. K. Pärtel.

42. Morchella conica Pers. In sylvis pratisque per regionem. Edulis. Conf. K. Pärtel.

Lichenes 81-100

81. Lepra viridis Schaer. Ad basim vetustum arborum, humidor. murorum Ubique per annum. This is not a lichen, instead there is a layer of green algae. Rev. A. Suija.

82. Lepra rubens fr. Ad cortices pracique vetust. Betularum, etc. Ubique. Mox expallescens! Rev. A. Suija: This is not a lichen, but an unidentified fungus.

83. Variolaria communis Ach. Ad cortices divers. arborum. Ubique. Lepra amara (Ach.) Hafellner. Det. A. Suija. The specimen is sorediate, soredia turn $\mathrm{KC}+$ violet.

84. Graphis scripta (L.) Ach. Ad cortices divers. arborum. Ubique. Conf. A. Suija.

85. Collema fasciculare L. Ad vetust. Salices, Populos, Quercos, etc. Non rare. Collema sp., det. A. Suija. This Collema specimen is either C. subnigrescens Degel. or C. nigrescens (Huds.) DC. The ascospores are filiform, 5-7-septate, 40-50 × 5-6 $\mu \mathrm{m}$.

86. Parmelia ceratophylla Wallr. Ad truncos Pinorum, etc. Ubique copiose. Hypogymnia physodes (L.) Nyl. Det. A. Suija. Soredia Pd + orange. 
87. Parmelia stellaris L. fr. Ad arbores et frutices, ubique copiose. Physcia aipolia (Ehrh. ex Humb.) Fürnr. Det. A. Suija.

88. Peltigera aphthosa (L.) Willd. Ad terram inter muscos, ad radices saxaque per regionem. Conf. I. Jüriado. The veins underside of the lichen thallus are wide. There is no indication about collecting site, but in Cryptogamenwelt it is said that the species is especially nice "bei Fall in Ehstland" (Dietrich, 1856, p. 149).

89. Peltigera canina L. Hoffm. Ad terram in sylvaticus. Ubique. Peltigera praetextata (Flörke ex Sommerf.) Zopf. Det. I. Jüriado. The rhizines underside of the lichen thallus are simple.

90. Calycium pusillum Flk. Wallr. Ad vetusta ligna, praecipue Salicum, Populorum, etc. Per regionem. Mycocalicium subtile (Pers.) Szatala. Conf. / Det. A. Suija. The ascospores are simple, brown, spindle-shaped, $8-9 \times 4 \mu \mathrm{m}$, asci $47 \times 4 \mu \mathrm{m}$. Dietrich referred in Cryptogamenwelt that this specimen as var. subtile Fr. that corresponds to M. subtile today (Dietrich, 1856, p. 149).

91. Chaenotheca chrysocephala (Ach.) Th. Fr. (as Calycium chrysocephalum Turn.) Ad cortices vetust. truncorum. Praecique Betularum, Pinorum, etc. Ubique copiose. Conf. A. Suija.

92. Biatora sphaeroides Dicks. g., muscorum. Ad muscos vetustum, ad basim truncorum muscosor. Per regionem minus rare. Bilimbia sabuletorum (Schreb.) Arnold. Det. A. Suija. Ascospores 4-6-celled, spindle-shaped, 16-23 × 5-7 $\mu \mathrm{m}$.

93. Trapeliopsis granulosa (Hoffm.) Lumbsch (as Biatora granulosa Ehrh.). In turfosis, ericetosis, non rara. Conf. A. Suija.

94. Icmadophila ericetorum (L.) Zahlbr. (as Biatora icmadophila L. fr.). Ad truncos mucosos, ad terram in turfosis, ericetosis, etc. Ubique. Conf. A. Suija.

95. Biatora aurantiaca fr. Ad corticem div. arbor. frondosarum e.g. Populorum. Per regionem. Gyalolechia flavorubescens (Huds.) Søchting, Frödén \& Arup. Det. A. Suija.

96. Cladonia squamosa Hoffm. Ad terram et ad vetust. truncos e.g. Betularum per regionem. Cladonia gracilis (L.) Willd. Det. A. Suija.

97. Cladonia pyxidata Tournef. L. Hoffm. Ad terram in ericetosis, ad truncos vetust, ubique copiose. Cladonia sp., rev. A. Suija. The specimen is definitely not C. pyxidata. The specimen lacks cortex, but most of the soredia are swept off, it represents $C$. fimbriata or any species of $C$. chlorophaea group. 
98. Cladonia cornuta (L.) Hoffm. In pinetis inter muscos, etiam ad truncos dive. vetust. arborum per regionem. Conf. A. Suija. The thallus reacts $\mathrm{Pd}+$ orange. 99. Platismatia glauca (L.) W. L. Culb. \& C. F. Culb. (as Cetraria glauca L. Ach. a, vulgaris / melanoplaca Wallr./Schaer.) Ad truncos ramosque div. arborum, praecique Pinorum. Ubique copiosa. Conf. A. Suija.

100. Platismatia glauca (L.) W. L. Culb. \& C. F. Culb. (as Cetraria glauca L. Ach., b, fallax / leucoplaca Wallr.) Ibidem, cum antecedente. Conf. A. Suija.

\section{Centuria VI}

Of the 100 specimens in total, Cyphella muscicola (no. 70) has been lost from its substrate, which leaves 99 specimens preserved. Eighteen Pucciniales and two Urocystidales were revised previously (Lepik, 1939; 1943), as were three powdery mildews (Lepik, 1943).

Fungi 1-80

72. Geoglossum difforme Fr. In umbrosus, arenosis pratis. Satis rare autumno.

Sabuloglossum arenarium (Rostr.) Hustad, A. N. Mill., Dentinger \& P. F. Cannon (as Microglossum arenarium Rostr.), det. A. Raitviir. In Dietrich (1856, p. 364) is written that it is collected in Keila-Joa.

73. Tympanis conspersa (Fr.) Fr. Ad emort. quam morbos. ramos div. arbor. frondis. e.g. Sorbi, Pyrorum, Alni, Betulae etc. Per anum ubique. Conf. K. Pärtel. Quite juvenile.

75. Trichopeziza sulphurea (Pers.) Fuckel (as Peziza sulpurea c. leucophaea Pers.) Ad caules div. plantar. e.g. Urticarum. Satis frequens. Conf. K. Pärtel. Ascospores $18-29 \times 2-3 \mu \mathrm{m}$, hairs turn violet in $\mathrm{K}$.

Lichenes $81-100$

81. Chrysothrix candelaris (L.) J. R. Laundon (as Lepra candelaris Ehrb.) Ad vetust. cortices Quercorum, Betularum et Pinorum. Per regionem. Conf. A. Suija.

82. Pulveraria farinosa. Cortices, muscos etc. obducens, in sylvis et ericetosis per regionem. There is a "dusty powder" on grass, the identity of which is impossible to establish, but it is certainly not a lichen. Rev. A. Suija.

83. Variolaria discoidea Pers. Ad cortices div. arborum frondis. Ubique copiose. Lepra amara (Ach.) Hafellner. Det. A. Suija. Soredia KC+ violet. The specimen has also a few apothecia intermixed with soralia, but without mature ascospores. 

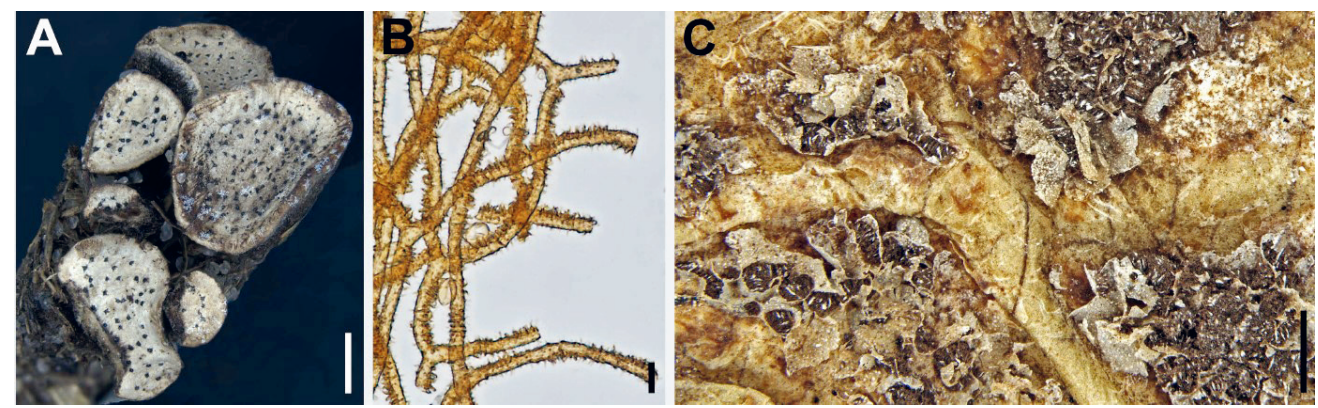

Figure 5. A. Stromata of Poronia puncata in Dietrich's Centuria V 16.

B-C. Myxomycetes. B-Arcyria oerstedii, capillitium, Dietrich's Centuria VII 47.

C-Physarum gyrosum, fruitbodies in Centuria VIII 81 (scale bars: $A=2 \mathrm{~mm}$, $\mathrm{B}=10 \mu \mathrm{m}, \mathrm{C}=1 \mathrm{~mm})$.

84. Gyrophora polyphylla b., deusta. Ad saxa litoralia, minus frequens. The specimen is stuck upside down, and therefore it is impossible to check if the specimen has isidia, a decisive characteristic for Umbilicaria deusta.

85. Physconia distorta (With.) J. R. Laundon (as Parmelia pulverulenta Fr.) Ad div. vetustos truncos. Per regionem. Conf. A. Suija.

86. Flavoparmelia caperata (L.) Hale (as Parmelia caperata L. Dill.) Ad truncos arborum, praecipue fructiferum, etiam ad saxa. Per regionem. Conf. A. Suija.

87. Peltigera venosa (L.) Hoffm. In humidis ad terram, ad fossarum margines etc. Perrara, Esthoniae coll. 1848. Conf. I. Jüriado. The specimen is stuck upside down, but since the specimen is small and with dark veins on the underside, we can confirm the determination.

88. Peltigera horizontalis L. Hoffm. Ad terram et ad saxa inter muscos, per regionem frequens. Peltigera leucophlebia (Nyl.) Gyeln. Det. I. Jüriado.

89. Nephroma resupinatum L. p. Ad truncos muscis involutis, praecipue Quercorum. Haud frequens. Nephroma laevigatum Ach. Det. A. Suija. The specimen has no isidia, and the medulla is yellow.

90. Biatora sphaeroides h., vernalis. Ad truncos, ad emort. muscos, ad terram, etc. Per regionem. Biatora sphaeroides (Dicks.) Hornem. Det. A. Suija. Ascospores 2-celled, 13-16 $\times 4 \mu \mathrm{m}$, all apothecial structures hyaline.

91. Dibaeis baeomyces (L. f.) Rambold \& Hertel (as Baeomyces roseus Pers.) In ericetosis, plerumque caespitose; hinc inde frequens. Conf. A. Suija. There is no locality data on the sheet, but in Cryptogamenwelt it is said this species is rather 
Kadri Pärtel

Ave Suija

Iryna Yatsiuk

rare and found near Jädivere, Velise and near Tallinn (Dietrich, 1856, p. 150).

92. Cladonia coccifera L. Cl. cornucopioides Fr. In ericetosis, pinetis arenosis etc. per regionem. Rev. A. Suija. Most probably, the specimen belongs to C. coccifera because of its red apothecia at the rim of podetium, and lack of soredia, but it is necessary to determine its lichen substances for final confirmation.

93. Cladonia fimbriata L. fr. a., brevipes, b. prolifera Wallr. Ad terram et ad truncos putridos, ubique in pinetis. Cladonia gracilis (L.) Willd. Det. A. Suija.

94. Cladonia vermicularis Ach. Lyn. / Cladonia subuliformis Hoffm. Inter muscos in sylvis et ericetosis. Satis frequens. Cladonia subulata (L.) Weber ex F. H. Wigg. Det. A. Suija. Thallus Pd+ orange.

95. Cladonia furcata (Huds.) Schrad. (as Cladonia furcata c, fruticosa Schaer.) Ad terram in pineti ericetosis. Ad terram in pinetis ericetosisque. Ubique. Conf. A. Suija. Thallus Pd + orange, $\mathrm{K}-$.

96. Cladonia rangiferina $\mathrm{L}$. b, incrassata Schaer. In pinetis inter muscos etc. Ubique per regionem. Cladonia stygia (Fr.) Ruoss. Det. A. Suija.

97. Cladonia deformis L. Hoffm. Ad terram inter muscos etc. in ericetosis per regionem. The specimen is damaged, and the characteristic features-presence of red apothecia and soredia on podetia-are not observable that makes confirmation of determination impossible. Rev. A. Suija.

98. Cladonia cervicornis subsp. verticillata (Hoffm.) Ahti (as Cladonia degenerans Wahlb. g, verticillata / prolifera Hoffm.) Ad terram inter muscos in pinetis. Per regionem. Conf. A. Suija.

99. Ramalina fastigiata (Pers.) Ach. (as Ramalina calicaris L. a., fastigiata (Pers.) Schaer. fr.) Ubique copiose ad truncos, ramos, sepes, etc. Conf. A. Suija.

100. Cetraria aculeata (Schreb.) Fr. (as Cornicularia aculeata Schreb. Ach.) Semel in ericetosis collegi, in arenosis collegi, Esthoniae, 1853. Conf. A. Suija.

\section{Centuria VII}

This material is organized in the same way as Centuria $\mathrm{V}$ with a handwritten list. Seven specimens have been fully lost $(9,17,42,73,89,96,99)$ and in 11 other, the fruitbodies are too rotten or only the substrate remains; for example, nos. 63 Peziza herbarum Pers., 65 Peziza virginea Batsch, 70 Peziza caesia Pers., 71 Peziza tiliacea Fr. Three taxa belong to myxomycetes. Only two Pucciniales and one Tilletiales have been revised previously (Lepik, 1939; 1943). 
Revised for this work:

47. Arcyria nutans DC. ad putrid ligna e.g. truncorum vetust. pinorum, aestateautumno per regionem. Arcyria oerstedii Rostaf. Det. I. Yatsiuk (Fig. 5B).

48. Trichia chrysosperma DC. Aestate-autumno ad ligna vetusta, minus rare. Trichia contorta (Ditmar) Rostaf. Det. I. Yatsiuk. Specimen is almost destroyed, consists of lower parts of the peridium, few elaters and spores.

49. Leocarpus vernicosus Lk. Ad folia, ramos dejectos, muscos graminaque, praecipe in pinetis, aestate-autumno, satis rare. Leocarpus fragilis (Dicks.) Rostaf. Conf. I. Yatsiuk. Specimen in bad condition.

57. Peziza variecolor Fr. Ad cortices vetust. e.g. Populorum, per annosum. Trichopeziza sp. Det. K. Pärtel.

58. Peziza coccinea Jacq. Verne ad ramos terrae obdectos, satis rare in agris et sylvis. Rev. K. Pärtel. Quite rotten, $c f$. Sarcoscypha sp.

59. Peziza papillaris Bull. ad ligna vetusta putrida per annum et per regionem. Det. K. Pärtel: juvenile Trichopeziza sp.

64. Humaria hemisphaerica (F. H. Wigg.) Fuckel (as Peziza hemisphaerica Hoffm.) Ad terram nudum humidam in sylvis et hortis, aestate-autumno, per regionem. Conf. K. Pärtel.

68. Peziza violacea Pers. ad terram humidam in locis carbonatis. Verne-autumno, per regionem. Rev. K. Pärtel: Peziza sp. Ascospores ornamented.

\section{Centuria VIII}

In this Centuria, there are 101 specimens (there are two substrate plants in one page), including 22 Pucciniales, 18 Erysiphaceae (Lepik, 1943) and 3 Ustilaginales (Lepik, 1939). The remainder need revision. One specimen belongs to the myxomycetes.

\section{Physarum confluens Pers.}

Ad caules foliaque Cucurbitacearum vivent, ad folia Lactucae sativae, aestateautumno. Satis rare. Physarum gyrosum Rostaf. Det. I. Yatsiuk (Fig. 5C).

90. Peziza girgensohni (mihi). Vere-aestate in pratis umbrosis, humidis ad folia vetusta Betulae alba, jam autumn dejecto. Satis rare, prope “Söttküll” Esthonia. In memoriam cl Girgensohni (Dorpatenis) balticae florae cryprogamicae huqusque optime meriti, hanc speciem novam nominare impulsus fui. Rev. K. Pärtel. Small 
Kadri Pärtel

Ave Suija

Iryna Yatsiuk

substipitate reddish brown apothecia on half of a leaf of Betula. Juvenile, no ascospores.

91. Peziza relicina Fr. ad sicc. caules Galiorum. Vere. Videtur mihi perrara. Trichopeziza subsulphurea (Svrček) Baral, det. K. Pärtel.

92. Lachnella villosa (Pers.) Donk (as Peziza villosa Pers.) ad caules plantar. Hiemeverne. Per regionem. Conf. K. Pärtel. This taxon belongs now to Agaricales, Basidiomycota.

\section{Centuria IX}

Fungal material of this volume is in a folder with cardboard covers, tied with a string. The specimens are unfixed, with loose handwritten labels, placed in pairs between thick filter paper sheets, which are numbered (1-100) by a blue stamp. The front cover of the folder is printed as in the bounded volumes. Leppik (Lepik, 1939) mentioned that he studied four copies of this Centuria, but only one of them is still preserved. Fungi of this Centuria are foliicolous or caulicolous, except "Leotia" circinans (Cudonia circinans (Pers.) Fr.) and Polyporus xanthus Fr. (Amyloporia xantha (Fr.) Bondartsev \& Singer). Most of the specimens are only a small piece of leaf or stalk, mainly in good condition, the material apparently having been well-dried after collecting. Leppik counted 29 specimens of Uredinales, three of Ustilaginales and 27 of Erysiphaceae (Lepik, 1939). In addition to these, species-rich genera like Sphaeria (11 specimens), Depazea (9) and Ectostroma (5) are in need of further revision in line with current taxonomy. 97. Peziza caulicola Fr. ad folia exarida Elymi et culmos arundinorum. Brunnipila palearum (Desm.) Baral, det. A. Raitviir 1976. Immature, no spores seen.

99. Cudonia circinans (Pers.) Fr. (as Leotia circinans Pers. $\beta$ nigripes /mihi/) in pinetis inter muscos, hinc inde. Conf. K. Pärtel. Rotten specimen.

\section{Fasciculi}

Dietrich's folders, named Fasciculi, are held in the Estonian Museum of Natural History. Fungal specimens in these folders are affixed to paper sheets, with loose handwritten labels (taxon, substrate, phenology), identical in style to those used in the Centuriae. Moreover, the majority of numbers on the labels correspond to the number order used for the same taxon in Centuriae, e.g. "IV 14" for Centuria IV number 14 (Fig. 6), but the materials of different Centuriae are intermixed. In conclusion, these materials, 630 specimens in total, represent leftovers from Centuriae I-II, IV-IX and 7 specimens from the lost Centuria III. 


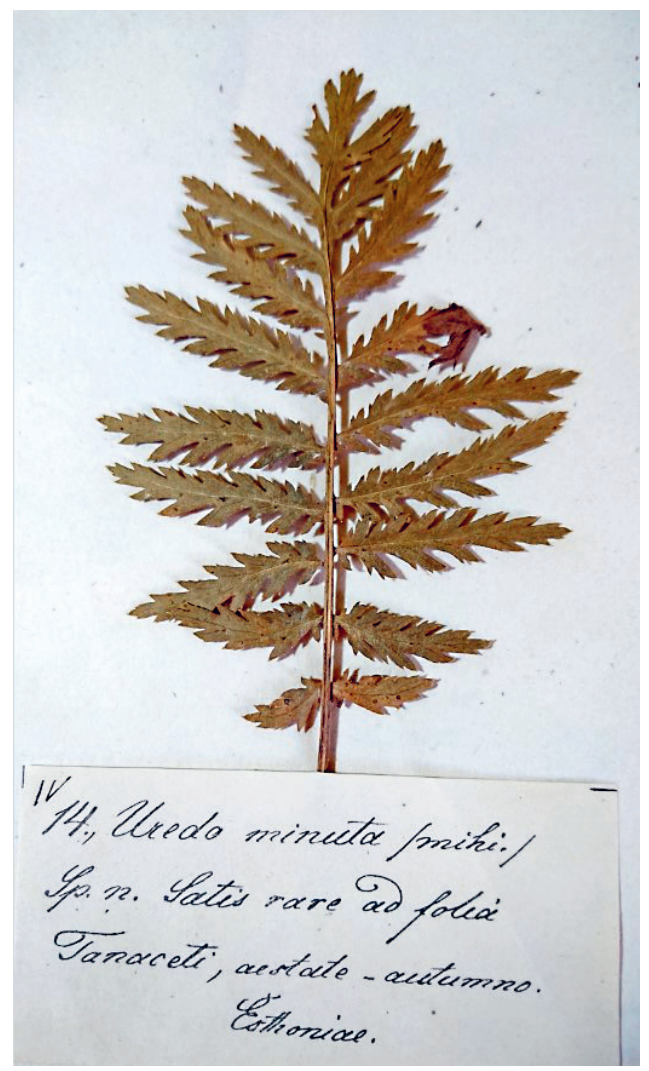

Figure 6. Fasciculus from Dietrich's Centuria IV, no. 14, with new species Uredo minuta H.A. Dietr. ex Sacc. (current name Puccinia tanaceti DC.)

Original titles:

Fasciculus I: I Coniomycetes, II Cryptomycetes. ELM³ 3800/Aj19: 3. Includes mostly taxa of Pucciniales (235 specimens)

Fasciculus: III Hyphomycetes, IV Mucorini. ELM 3800/Aj19:4 (40 specimens)

Fasciculus III: Mycetini, Tremellini, Discomycetes, Hymenomycetes. ELM 3800/ Aj19:5 (90 specimens)

Fasciculus IX: Myxogastres, X: Sphaeronemae, XI: Gasteromycetes, XII: Pyrenomycetes ELM 3800/Aj19:6 (226 specimens)

3 ELM indicates the number of the archival document folder in the Estonian Museum of Natural History. 
These Fasciculi need revision because in some cases, the specimens may represent species morphologically similar to those presented in the Centuriae or specimens from a different host plant, so the identifications require confirmation.

The folder ELM 3800/Aj19: 9 (no headline) contains additional 39 specimens of lichenized fungi corresponding mostly to Centuria IV and VI with a few exceptions listed below:

65. Illosporium roseum Fr. I Coccochloris rosea Spr. I Palmella rosea Lynge / Sclerotium granuatum Schuhm. / Tubercularia rosea Pers. Ad lichenes truncosque per annum praecque automno-verne per regionem. There is a separate sheet, on which thalli of Parmelia sulcata Taylor and Physcia adscendens H. Olivier, typical hosts for various sporodochial lichenicolous fungi like Illosporiopsis christiansenii (B.L. Brady \& D. Hawksw.) D. Hawksw., Marchandiomyces aurantiacus (Lasch) Diederich \& Etayo, etc., are glued. Currently there is no sign of the fungus, but it is highly possible that loose conidia have been swept off in the course of time. Rev. A. Suija.

90. Biatora sphaeroides Mycobilimbia tetramera (De Not.) Vitik., Ahti, Kuusinen, Lommi \& T. Ulvinen. Det. A. Suija. Apothecia brownish, apothecial structures pigmented (microscope), ascospores 4-celled, spindle-shaped, 16-20 $\times 6-7 \mu \mathrm{m}$.

94. Cladonia vermiformis Cladonia cornuta (L.) Hoffm. with undetermined lichenicolous fungus. Det. A. Suija.

98. Cladonia deformis. Rev. A. Suija. The specimen in the envelope is damaged but is definitely not $C$. deformis. It could be $C$. uncialis but the confirmation is impossible.

99. Bryopogon jubatus. This envelope contains two species, Bryoria fuscescens (Gyeln.) Brodo \& D. Hawksw. and Alectoria sarmentosa (Ach.) Ach., det. A. Suija. 


\section{What can we learn from the historical collections?}

Although an interest in mycology was just a single episode in the life of Heinrich August Dietrich, his contribution to mycological research is an inspiring example for subsequent generations. Dietrich was one of those amateur scientists whose monographs about specific groups of organisms were published in the 19th century by the newly established Die Dorpater Naturforscher-Gesellschaft. From Dietrich's notes, it can be learned that members of this society, among them $G$. C. Girgensohn and A. von Bunge, actively exchanged collections with each other. We can also see evidence of a network of correspondence between professionals from the university and less-experienced naturalists keen in collecting and documenting observations. And therefore there are still historical records to discover and vouchers to study.

In the course of checking the specimens of ascomycetes that are more than 160-years old, we have found the oldest vouchers for several Estonian redlisted fungi (according to the last assessment by Saar et al., 2019) and lichens (Lóhmus et al., 2019). Poronia punctata ascostromas, collected in the 1850 s, have been well preserved in Dietrich's Centuria V. The category of the International Union for Conservation of Nature of this species is Critically Endangered (Saar et al., 2019), as it was last been seen in Estonian Western islands in 1960 and was reported as "wanted" (Pärtel et al., 2019). The coastal earth tongue fungus, Sabuloglossum arenarium (featured in Centuria VI) is categorized as Vulnerable (Saar et al., 2019). Among the lichens, the most remarkable findings are Peltigera venosa, evaluated recently as Critically Endangered, and Dibaeis baeomyces, Flavoparmelia caperata, Lasallia pustulata, Nephroma laevigatum and Ramalina calicaris, all classified as Endangered, and Alectoria sarmentosa and Lobaria pulmonaria, classified as Vulnerable.

Although the assessment of myxomycetes for their conservation status has not yet been carried out in Estonia, the revision of historical collections nevertheless resulted in several interesting findings. One is the well-preserved specimen 81 of Centuria VIII, assigned by Dietrich to Physarum confluens, which is now treated as a doubtful taxon probably comprising several species (Lado, 2005-2010). Upon revision, it proved to be Physarum gyrosum, thereby representing a new record for Estonia, never reported in subsequent years. Another myxomycete specimen, 47 of Centuria VII, labelled originally as Arcyria nutans although quite destroyed, preserves a characteristic spiny capillitium that very likely belongs to $A$. oerstedii. The only existing report of $A$. oerstedii since then appears in the Checklist of 
Estonian Fungi (Järva \& Parmasto, 1980), but curiously, this reference-based record refers back to Dietrich's Cryptogamenwelt as a synonym for what Dietrich reported as A. flexuosa Rabenh. However, A. flexuosa is currently treated as a probable synonym of $A$. incarnata rather than $A$. oerstedii (Lado, 2005-2020), so the identity of Dietrich's $A$. flexuosa remains unclear. Unfortunately, specimens denoted as A. flexuosa have not yet been found in Centuriae for revision. Even though dealing with old collections often goes hand in hand with taxonomic intricacies, we may suppose that Dietrich collected A. oerstedii, and that this species has not yet been reported by subsequent researchers.

In conclusion, in this paper, we focused on the earliest preserved records of Discomycetes, lichenized fungi and myxomycetes, but these oldest collections may hold more secrets. Several specific fungal groups-polypores, Dietrich's new taxa, etc.—are waiting to be revised.

\section{Acknowledgements}

We thank Inga Jüriado (University of Tartu) for identifing specimens. MarjaLiisa Kämärä and Jana-Maria Habicht (Estonian Museum of Natural History) kindly helped to access the collections in Tallinn. Gintaras Kantvilas (Hobart, Tasmania) is thanked for linguistic editing. Heldur Sander inspired us to initiate this work and suggested important sources about the topic.

\section{References}

Anonymous (1855-1856a), 'Sitzung des Vereins am 17. December 1856,' Correspondenzblatt des Naturforschenden Vereins zu Riga, 1855/1856, vol. 9, no. 12, p. 165.

Anonymous (1855-1856b), 'Neuaufgenommone Mitglieder des N. V.,' Correspondenzblatt des Naturforschenden Vereins zu Riga, 1855/1856, vol. 9, no. 12, p. 168.

Arefyev, L. A. (1916), 'Vidy roda Uromyces Pribaltiiskogo kraia,' Izvestiia i trudy sel'skokhoziaistvennogo otdeleniia Rizhskogo politekhnikuma [Nachrichten und Arbeiten des Landwirtschaftsabteilung am Rigaische Polytechnikum], vol. 3, no. 2, pp. 117-156.

Bucholtz, F. (1905), 'Die Pucciniaarten der Ostseeprovinzen Russlands,' Archiv für Naturkunde Liv-, Ehst- und Kurlands, vol. 13, no. 1, pp. 1-60. 
Dietrich, A. (1864), 'Über vernachlässigte und unbenutzte Gemüse- und Küchengewächse,' Mittheilungen der Kaiserlichen Freien Ökonomischen Gesellschaft zu St. Petersburg, vol. 21, no. 4, pp. 241-257.

Dietrich, A. (1865), 'Ueber den Bestand der Obstsorten in Ehstland und Acclimatisationsversuche mit neu eingeführten Arten,' Mittheilungen über die Wirksamkeit des Ehstländischen Gartenbau-Vereins zu Reval, 1864, vol. 2, pp. 36-47.

Dietrich, H. A. (1854), 'Acclimatisationsversuche im Norden, als Beitrag zur Landschaftsgärtnerei,' Mittheilungen der Kaiserlichen freien Ökonomischen Gessellschaft zu St. Petersburg vol. 1, pp. 49-64, vol. 2, pp. 181-215.

Dietrich, H. A. (1856), 'Blicke in die Cryptogamenwelt der Ostseeprovinzen,' Archiv für die Naturkunde Liv-, Ehst-und Kurlands, vol. 2, no. 1, pp. 261-414.

Dietrich, H. A. (1859), 'Blicke in die Cryptogamenwelt der Ostseeprovinzen,' Archiv für die Naturkunde Liv-, Ehst-und Kurlands, vol. 2, no. 1, pp. 487-538.

Dietrich, H. A. (1860), 'Die Birke, ein Mikrokosmos,' Illustrierter Revalscher Almanach für das Jahr nach Christi Geburt, 1859, Reval, pp. 53-83.

Dietrich, H. A. (1861), 'Vergleichende Bilder aus der niederen Pflanzenwelt,' Mittheilungen der Ehstländischen Literarischen Gesellschaft, vol. 2, pp. 26-45.

Dietrich, H. A. (1865), 'Alphabetisch Geordnetes Verzeichniß der Zierbäume und Sträucher Welche in der Gärten der Provinz Ehstland etc,' Mittheilungen über die Wirksamkeit des Ehstländischen Gartenbau-Vereins zu Reval, vol. 2, pp. 12-35.

EAA (1699-1939), 'HerBalt: baltisaksa genealoogilised allikad' [HerBalt: Baltic German genealogical sources], Genealoogiliste materjalide kollektsioon Törne arhiiv. Dietrich, Dietz - Ditzel, Diewel, Differt, EAA.4918.1.342, National Archives of Estonia, Tartu.

EAA (1863-1864), 'Eestimaa kuberneri kantselei' [Office of Governorate of Estonia], Akte betreffend die Erhebung des Revalschen Kunst Gärtners August Dietrich in den Persönlichen Ehrenbürgerstand, EAA.29.3.5543, National Archives of Estonia, Tartu.

EAA (1879), 'Tallinna Liikumata Varanduse Obligatsioonitoimikud. Dietrich, August,' EAA.4489.2.180, National Archives of Estonia, Tartu.

Estonian Manors (n.d.), Eesti möisaportaal [Home page]. Retrieved from http: //www. mois.ee/ [accessed 20 Feb 2021]

Fischer, G. B. (1791), Versuch einer Naturgeschichte von Livland, Königsberg: F. Nicolovius, pp. 671-682.

Friebe, W. C. (1805), Oekonomisch-technische Flora für Liefland, Ehstland und Kurland, Riga: C. J. G. Hartmann, pp. 295-308.

Fries, E. M. (1836-1838), Epicrisis Systematis mycologici: seu synopsis hymenomycetum. I-XII, Uppsala: Typographia Academica.

Grindel, D. H. (1803), 'Botanisches Taschenbuch für Liv-, Cur- und Ehstland,' Riga: C. I. G. Hartmann, pp. 327-338. 
Kadri Pärtel

Ave Suija

Iryna Yatsiuk

Hupel, A. W. (1777), Topographische Nachrichten von Lief- und Ehstland. Gesammelt und herausgegeben durch August Wilhelm Hupel, Bd. 2, Riga: J. F. Hartknoch, pp. 486-524.

Index Fungorum (2021), [Home page]. Retrieved from http://www.indexfungorum.org [accessed 15 Feb 2021]

Järva, L. \& Parmasto, E. (1980), 'Eesti seente koondnimestik. List of Estonian fungi with host index and bibliography,' Scripta Mycologica 7. Tartu: Eesti NSV TA Zooloogia ja Botaanika Instituut.

Kalling, K. (2013) 'Prof. Elmar Leppiku tööst paguluses,' Agraarteadus / Journal of Agricultural Science, vol. 24, pp. 95-98.

Kask, K. (1960), 'A. H. Dietrich-esimene mükoloog Eestis,' Eesti Loodus, vol. 6, pp. 360-362.

KNAB (n.d.), Eesti kohanimede andmebaas. Place Names Database [Home page], Eesti Keele Instituut. Retrieved from https://www.eki.ee/knab/knab.htm [accessed $1 \mathrm{Feb}$ 2021]

Kongo, L. (2003). 'Eesti Looduseuurijate Seltsi 150 tegevusaastat 1853-2003' [150 active years of the Estonian Naturalists' Society 1853-2003], Eesti Looduseuurijate Selts, Tallinn: Teaduste Akadeemia Kirjastus.

Kongo, L. (2016), 'Saksa-Eesti kohanimed' [German-Estonian place names], Abiks loodusevaatlejale 100, Tartu: Eesti Teaduste Akadeemia \& Eesti Looduseuurijate Selts.

Lado, C. (2005-2021), An On-line Nomenclatural Information System of Eumycetozoa, Real Jardín Botánico, CSIC, Madrid, Spain [Home page]. Retrieved from http:// www.nomen.eumycetozoa.com [accessed 16 Feb 2021]

Lepik, E. (1928), 'Beiträge zur Nomenklatur der Ostbaltischen Pilzflora II. Revision der "Plantarum florae cryptogamarum" von H. A. Dietrich, cent I, Revaliae, 1852,' Sitzungberichte der Naturforscher-Gesellschaft bei der Universität Dorpat I Looduseuurijate Seltsi Aruanded, vol. 35, nos. 1-2, pp. 239-259.

Lepik, E. (1931), 'Beiträge zur Nomenklatur der Ostbaltischen Pilzflora II: Revision der Plantarum florae balticae cryptogamarum von H. A. Dietrich,' Sitzungsberichte der Naturforscher-Gesellschaft bei der Universität Dorpat / Looduseuurijate Seltsi Aruanded, vol. 37, nos. 3-4, pp. 63-88.

Lepik, E. (1938), 'Beiträge zur Nomenklatur der Ostbaltischen Pilzflora. III,' Sitzungberichte der Naturforscher-Gesellschaft bei der Universität Dorpat I Looduseuurijate Seltsi Aruanded, vol. 43, nos. 3-4, pp. 226-242.

Lepik, E. (1939), 'Beiträge zur Nomenklatur der ostbaltischen Pilzflora. IV-VI,' Mittheilungen der Phytopathologischen Versuchsstation der Universität Tartu / Tartu Ülikooli Taimehaiguste-katsejaama teated, vol. 56, pp. 1-80.

Lepik, E. (1940), 'Beiträge zur Nomenklatur der ostbaltischen Pilzflora VII. Eine kleine Pilzkollektion von A. H. Dietrich,' Mittheilungen der Phytopathologischen Versuchsstation der Universität Tartu / Tartu Ülikooli Taimehaiguste-katsejaama teated, vol. 59, pp. 1-15. 
Lepik, E. (1943), 'Beiträge zur Nomenklatur der ostbaltischen Pilzflora. VIII-X,' Mittheilungen der Phytopathologischen Versuchsstation der Universität Tartu / Tartu Ülikooli Taimehaiguste-katsejaama teated, vol. 63, pp. 254-364.

Lóhmus, P.; Marmor, L.; Jüriado, I.; Suija, A.; Oja, E.; Degtjarenko, P. \& Randlane, T. (2019), 'Red List of Estonian lichens: revision in 2019,' Folia Cryptogamica Estonica, vol. 56, pp. 63-76. https://doi.org/10.12697/fce.2019.56.07

Parmasto, E. (2009), 'Eesti seeneteaduse pikk ja habras tekketee. Kolme sellesse juhuslikult sattunud mehe elutee käänakutest' [The long and fragile evolution of Estonian mycology. On the twists and turns in the lives of three men who happened to become involved in it], in I. Rohtmets \& T. Kukk (eds.) Lehed ja tähed 5. Vaim ja aeg, Tallinn: MTÜ Loodusajakiri, pp. 36-45.

Pärtel, K.; Póldmaa, K. \& Saar I. (2019), 'Aita leida haruldasi ja ohustatud seeni' [Help us find rare and endangered fungi], Eesti Loodus, vol. 8, pp. 22-23.

Pärtel, K.; Suija, A. \& Yatsiuk, Y. (2021), 'The mycological collection of G. C. Girgensohn from the middle of the 19th century,' Folia Cryptogamica Estonica, vol. 58 (in press).

Rabenhorst, G. L. (1844-1848), Kryptogamen-Flora oder Handbuch zur Bestimmung der kryptogamischen Gewächse Deutschlands, der Schweiz, des LombardischVenetianischen Königreich und Istriens, Leipzig: E. Kummer.

Revalsche Zeitung (1897), 'Tageschronik. Nekrolog,' no. 277, December 9.

Saar, I.; Oja. J.; Póldmaa, K.; Pärtel, K.; Zettur, I. \& Kóljalg, U. (2019), 'Red List of Estonian Fungi-2019 update,' Folia Cryptogamica Estonica, vol. 56, pp. 117-126. https://doi.org/10.12697/fce.2019.56.12

Sander, H. (2019), 'Saateks (Heinrich August Dietrich. Looduspilte Eestimaast. Tôlkinud Hanna Miller),' Akadeemia, vol. 1, pp. 103-118. [Afterword in Estonian to the translation of H. A. Dietrich's speech 'Naturbilder aus Estland', published in Baltische Monatsschrift, Jahrg 5 (1864), vol. X, no. 5, pp. 389-409]

TLA (1834-1905), Tallinna Oleviste Kogudus [Tallinn's Oleviste congregation]. Abielude registreerimise raamat [Marriage register], TLA.236.1.20a, Tallinn City Archives.

TLA (1857-1885), Tallinna Oleviste Kogudus. Verzeichniss der Geborenen und Getauften. TLA.236.1.14b, Tallinn City Archives.

Vimba, E. (2009), 'History of mycobiota research of Latvia: Chronology till the middle of the 20th century,' Proceedings of the Latvian Academy of Sciences, Sect B, vol. 63, no. 6, pp. 287-292. https://doi.org/10.2478/v10046-010-0005-x

Weinmann, J. A. (1836), Hymeno- et Gasteromycetes hucusque in imperio Rossico observatos, Inpensis Academiae Imperialis Scientiarum, Petropoli.

Zigra, J. G. (1799), 'Skizzen der Botanik in Liefland,' in J. J. Schmidt (ed.) Botanisches Jahrbuch für Jedermann, 1, Lüneburg, pp. 205-214. 
Kadri Pärtel, PhD is a research fellow of mycology at the Institute of Ecology and Earth Sciences, University of Tartu, studying fungal taxonomy in order Helotiales (Ascomycota). She is a curator of mycological collections at Estonian University of Life Sciences, and is responsible for biggest Estonian fungarium.

Ave Suija, PhD is an associate professor in lichenology at the Institute of Ecology and Earth Sciences, University of Tartu, who specializes in taxonomy of lichenicolous (lichen-habiting) fungi. She is also a curator of the Fungarium of the University of Tartu.

Iryna Yatsiuk is a PhD student at the University of Tartu. Her research area is in taxonomy, biodiversity and ecology of myxomycetes. 